\title{
Biodegradation of propiconazole by newly isolated Burkholderia sp. strain BBK_9
}

\author{
Praveen Satapute $^{1} \cdot$ Basappa Kaliwal $^{1,2}$
}

Received: 4 January 2016/Accepted: 26 April 2016/Published online: 11 May 2016

(c) The Author(s) 2016. This article is published with open access at Springerlink.com

\begin{abstract}
The isolation of propiconazole (PCZ) degrading bacterium BBK_9 strain was done from paddy soil, and it was identified as Burkholderia sp. based on the morphological characteristics and biochemical properties combined with $16 \mathrm{~S}$ rRNA gene sequencing analysis. It has been seen that the factors such as temperature and $\mathrm{pH}$ influence the biodegradation process. The role of plasmid was studied in the degradation process by plasmid curing method. The PCZ acts as the sole carbon source and as energy substrate which can be utilized by the strain for its growth in Mineral salt medium and degraded $8.89 \mu \mathrm{g} \mathrm{ml}^{-1}$ of PCZ at $30{ }^{\circ} \mathrm{C}$ and $\mathrm{pH} 7$ within 4 days. During the bioconversion process of PCZ, three metabolite were formed such as 1-(2,4-dichlorophenyl)-2-(1H-1,2,4-triazol-1-yl) ethanone, 1-[2-(4-chlorophenyl) ethyl]-1H-1,2,4-triazole and 1-ethyl$1 H-1,2,4$-triazole. The LD50 value of BBK_9 strain was determined with acridine orange which resulted in $40 \mu \mathrm{g} \mathrm{ml}^{-1}$ at cell density of 0.243 at $660 \mathrm{~nm}$. Furthermore, plasmid curing was done using LD50 concentration and from that three plasmids got cured in the sixth generation. It was found that, cured strain was able to degrade $7.37 \mu \mathrm{g} \mathrm{ml}^{-1}$ of PCZ, indicating the plasmid encoded gene were not responsible for the PCZ degradation. On the source of these outcomes, strain BBK_9 can be used as potential strain for bioremediation of contaminated sites.
\end{abstract}

Basappa Kaliwal

b_kaliwal@yahoo.com

1 Department of Microbiology and Biotechnology, Karnatak University, Dharwad, Karnataka, India

2 Department of Microbiology and Biotechnology, Davangere University, Davangere, Karnataka, India
Keywords Propiconazole $\cdot$ Biodegradation $\cdot$ Burkholderia sp. metabolites · Plasmid curing

\section{Introduction}

The economy of India is largely depend on the agricultural production, due to the implementation of advanced technologies in the form of bio fertilizers, chemical fertilizers and different forms of pesticides have made possible to increase the quality and quantity of field products (Ramudu et al. 2011). Moreover, attention on the pesticides has increased during the recent times due to their versatile nature and various modes of action. Currently, triazole fungicides are the extensively used among the all fungicides for the protection of standing crops against plant pathogens. Whereas, the toxicity and non-target effect of azole fungicides are vastly under represented.

Propiconazole (PCZ) is a triazole foliar fungicide, which is used in the agriculture. The yearly intake of this fungicide is about $7373 \mathrm{~g}$ a.i. $\mathrm{ha}^{-1}$. The degradation of pesticides by microorganisms is gaining the extensive attention in the agricultural field and environmental microbiology. Interestingly, only few literatures are there which are dealing with the fungicide degradation by bacteria and in the previous years, many experiments have suggested that bacterial community are effective degraders of many different classes of fungicides: vinclozolin (Lee et al. 2008), tubeconazole (Nicole et al. 2009), captan (Megadi et al. 2010), benzimidazole (Cycon et al. 2011) and thiram (Sherif et al. 2011) and is necessary since PCZ biodegradation was not thoroughly investigated with the exception of Sarkar et al. (2009). Moreover, previously available reports are mentioned that PCZ utilization by microorganisms is not possible because of its ability to strongly 
adsorb with the soil's organic matter (Kloskowski et al. 1987; Ekler 1988; Woo et al. 2010). Similarly, laboratory scale degradation has been conducted in the different soils using commercial grade of PCZ alone or the mixture with benazone, dichlorprop and 2-methyl-4-chlorophenoxyacetic acid. It was revealed that the highest persistence of PCZ was found in agricultural soil since its traces were seen even after 84 days duration of experiment. (Thorstensen and Lode 2001). As per the technical information bulletin for PCZ, the half life ranges from low 96 days in a sandy loam to 575 days in a silt loam. Similarly, PCZ degradation by photolytic method in water is as long as 249 days. Thus, there is need of effective and cost friendly techniques which can degrade the PCZ from contaminant sites.

The isolate grown in respective medium is necessary to produce important metabolites which are precursors of degradation and it is also important to know that, potent microorganisms are likely to yield important new information on how the isolated bacteria is capable of degrading the toxic pesticide that prevails in the agricultural soil. Therefore, this study was under taken to isolate the potent microorganism which will prove their capability to metabolize PCZ under the liquid medium in given optimal conditions. Also, the function of plasmid and ability of cured strain in degrading the PCZ was investigated.

\section{Materials and methods}

\section{Chemicals and reagents}

Propiconazole was obtained from Nagarjuna Agrichem Co., Ltd (Srikakulam, India), ethyl acetate and acetonitrile of HPLC grade were purchased from the HiMedia and all other chemicals, and reagents were used for this experimental study are highest analytical grade.

\section{Soil samples and media}

For this study, soil was collected from the uppermost layer $(0-10 \mathrm{~cm})$ of paddy field with the pesticide application situated in the Koppal district of Karnataka, India. The mineral salt media (MSM) (Seubert 1990) was used for this study.

\section{Isolation of PCZ utilizing bacteria}

The samples of soil which were collected from the different places were aseptically brought to the laboratory, $1 \mathrm{~g}$ of sieved soil was added in $100 \mathrm{ml}$ of MSM and the flasks were placed in the incubator shaker at $30{ }^{\circ} \mathrm{C}$ in $100 \mathrm{rpm}$ for $1 \mathrm{~h}$. Further, $10 \mathrm{ml}$ of soil suspension was inoculated to
$100 \mathrm{ml}$ of sterile MSM broth containing $1 \mu \mathrm{g} \mathrm{ml}^{-1}$ of PCZ as the only carbon source and energy substrate, incubation of all the flasks was done for 7 days at $30{ }^{\circ} \mathrm{C}$ in $120 \mathrm{rpm}$. After the incubation period the serial dilution of media was done up to $10^{-7}$ and appropriate dilutions $\left(10^{-5}, 10^{-6}\right)$ were inoculated in nutrient agar (NA) medium containing PCZ $\left(1 \mu \mathrm{g} \mathrm{ml}^{-1}\right)$ and all the colonies that were appeared on the NA were purified by quadrant streak method and stored at $4{ }^{\circ} \mathrm{C}$.

\section{Screening and acclimatization}

Several different colonies were isolated, all colonies that were appeared on the NA were examined for their PCZ utilizing capacity depending upon the colony count on mineral salt agar medium (MSAM) in different concentration of PCZ (2 and $10 \mu \mathrm{g} / \mathrm{L}$ ). Further, highly potent strain was acclimatized for the better development and utilization of PCZ degrading bacterium.

\section{Identification of $\mathrm{PCZ}$ utilizing bacteria}

The potent PCZ utilizing soil isolate was identified as per the morphological, Gram's characteristics and biochemical tests. Further, 16S rRNA sequencing was done at Xcelris genomics, Ahmedabad, India. Isolation of bacterial genomic DNA was done using xcelgen genomic DNA isolation kit and bacterial 16S rRNA gene fragment was amplified by PCR (Eppendorf Thermal Cycler) from genomic DNA using $16 \mathrm{~S}$ gene universal primers: $8 \mathrm{~F}$ and 1492R. Further, amplified PCR product was purified using xcelgen gel extraction kit. After determination of purified DNA, sequencing was done using automated DNA sequencing on ABI 3730xl Genetic Analyzer (Applied Biosystems, USA). Sequencing was done using Big Dye ${ }^{\circledR}$ Terminator v3.1 Cycle. Further, to perform the pairwise/multiple sequence alignment, the CLUSTALW tool was used and phylogenetic tree was constructed by the neighbor-joining method using bootstrap test (1200 replicates) (Saitou and Nei 1987), the evolutionary distance was computed using the MEGA 7 package by Tamura and Nei (1993) method and sequence of organism was deposited in the gene bank with the accession number LC099979.

\section{Utilization of PCZ by Burkholderia sp. BBK_9 strain}

Propiconazole resistant strain was pre cultured in nutrient broth at $30{ }^{\circ} \mathrm{C}$ in rotary shaker, and $3 \times 10^{6} \mathrm{cell} \mathrm{ml}^{-1}$ from the same media was inoculated in $100 \mathrm{ml}$ of liquid MSM containing $10 \mu \mathrm{g} \mathrm{ml}^{-1}$ of PCZ which acts as sole carbon source and growth substrate, then incubated at $30{ }^{\circ} \mathrm{C}$ in rotary shaker with $120 \mathrm{rpm}$. The cultures were periodically collected and measured the OD at $600 \mathrm{~nm}$ for 
cell growth, and bacterial suspension of all samples was centrifuged at $10,000 \mathrm{~g}$ for $15 \mathrm{~min}$ at $4{ }^{\circ} \mathrm{C}$. Further, culture filtrates were extracted with the ethyl acetate in rotor flash evaporator (Buchirotavapor R 210) and the residues were dissolved in the acetonitrile (HPLC grade) to examine the utilization of PCZ by UV spectrophotometer (Hitachi U 2900) at $220 \mathrm{~nm}$. All the tests were performed in three replicates. Percentage of PCZ degradation was calculated by formula which was previously mentioned by the Rokade and Mali (2014).

$\%$ of propiconazole degradation $=\mathrm{Ab}-\mathrm{Aa} / \mathrm{Ab} \times 100$

where, $\mathrm{Ab}$ is initial percentage of PCZ in MSM (before degradation) and Aa is percentage of PCZ after 4 days.

\section{Extraction of metabolites by preparative HPLC}

The extraction and purification of metabolites was done by the preparative HPLC on an Agilent Zorbax SB-C18 preparative column $(250 \times 9.4,5 \mu \mathrm{m})$. For the preparation of the three fractions, chromatographic peaks were collected at the exit of the detector into three different pools. Subsequently, the compounds or the pools were concentrated by removing/evaporating the solvent.

\section{Biodegradation analysis}

To quantify the degradation rate of PCZ by BBK_9 strain, the HPLC method was followed with little modification and was described by Bromilow et al. (1999). Briefly, $20 \mu \mathrm{l}$ of test sample was injected into HPLC Agilent 1260 fitted with quaternary pump, auto sampler and variable wavelength UV detector with $\mathrm{C} 18$ column (diameter $150 \times 4.6 \mathrm{~mm}$ ) having particle size 5 micron and elution of samples were done at $1.5 \mathrm{~min} \mathrm{ml}^{-1}$ with the mobile phase methanol + water (70:30). Mass spectrum (MS) was used for the analysis of metabolites (Shimadzu). One microliter of each sample was examined at MS by conditions: the transfer line temperature was $240{ }^{\circ} \mathrm{C}$, with $230{ }^{\circ} \mathrm{C}$ ion trap and $120{ }^{\circ} \mathrm{C}$ manifold temperature. Full-scan $(60-550 \mathrm{~m} / \mathrm{z}$ ) EI (auto mode) with $10 \mathrm{~mA}$ filament current was used for MS analysis from 5-31 min, which gave $2.7 \mathrm{scans} / \mathrm{s}$. Target automatic gain control was 15,000, and the multiplier voltage was $1450 \mathrm{~V}$. The mass scan range at 1000 in the electron ionization mode (EI).

\section{Effect of temperature and $\mathrm{pH}$ on biodegradation of PCZ}

The optimal condition required for degrading PCZ was tested in MSM amended with the PCZ $\left(10 \mu \mathrm{g} \mathrm{ml}^{-1}\right)$, the
$\mathrm{pH}$ tolerance of the isolate necessary for degrading PCZ was examined at $\mathrm{pH}$ values of among 5.0-9.0 and $\mathrm{pH}$ of MSM was adjusted using the $1 \mathrm{~N} \mathrm{NaOH}$ and 1N HCL. Similarly, optimum temperature conditions were studied ranging between 20 and $60{ }^{\circ} \mathrm{C}$. The degradation percentage was monitored by the UV spectrophotometer (Hitachi U 2900) at $220 \mathrm{~nm}$. All trials were performed in three replicates and in flasks which were not inoculated served as control.

\section{LD 50 value determination and plasmid curing of isolate BBK_9}

\section{LD 50 value determination}

The bacterial isolate BBK_9 was grown in nutrient broth for $18 \mathrm{~h}$ and inoculated $(0.1 \mathrm{ml})$ into nutrient broth tubes $(5 \mathrm{ml})$ with different concentrations of acridine orange (5-50 $\left.\mu \mathrm{g} \mathrm{ml}^{-1}\right)$. Control tube without acridine orange was also maintained. The culture was grown for $24 \mathrm{~h}$ at $37{ }^{\circ} \mathrm{C}$ and the biomass was measured at $660 \mathrm{~nm}$. The OD values of treated samples were compared with that of control and LD50 concentration was determined.

\section{Plasmid curing}

Plasmid curing of isolate BBK_9 strain was determined by the LD50 concentration was used to treat the bacterial isolate for five to six generations. The inoculation of test organism was done in $25 \mathrm{ml}$ of nutrient broth which was autoclaved and incubated at $37{ }^{\circ} \mathrm{C}$ for $18 \mathrm{~h}$. Five tubes of nutrient broth containing LD50 concentrations of acridine orange were prepared and $18 \mathrm{~h}$ old test organism was inoculated $(1 \%)$ in tube no. 1 . The control tubes without acridine orange were also prepared and inoculated, as mentioned earlier, the incubation was done at $37^{\circ} \mathrm{C}$ for 24 h. $1 \%$ culture from tube no. 1 was inoculated to tube no. 2 and incubated further for $24 \mathrm{~h}$. This serial inoculation was continued till plasmid curing was attained. The presence/absence of plasmid was observed by running it on $1 \%$ agarose gel by isolating the plasmid at every generation. Meanwhile, the plasmid cured BBK_9 strain was examined for its capability for degrading PCZ.

\section{Statistical analyses}

All Experiments were carried in a three independent replicates. Analysis of data was done by one way ANOVA variance SPSS version 20.0 software and data were denoted as means \pm standard errors. The difference among the each means were located using Duncan's test $(P<0.05)$. 


\section{Results}

\section{Isolation, screening and characterization of PCZ utilizing bacteria}

Total of 11 strains (BBK_1-11) were isolated from the paddy cultivated soil. Quadrant streak method was utilized for purifying all strains on nutrient agar plates containing PCZ $\left(1 \mu \mathrm{g} \mathrm{ml}^{-1}\right)$. Further, strains were screened for their ability to utilize PCZ in different concentrations $\left(2-10 \mu \mathrm{g} \mathrm{ml}^{-1}\right)$. As a result, BBK_9 strain was found most promising candidate for the utilizing of $\mathrm{PCZ}$ with a substantial growth in the all concentration. For the better enhancement of degradation process BBK_9 strain was acclimatized in MSM amended with PCZ $\left(10 \mu \mathrm{g} \mathrm{ml}^{-1}\right)$.

\section{Identification of BBK_9 strain}

The BBK_9 strain was found Gram negative, non-motile, aerobic, rod shape. Biochemically it was found catalase and urease positive. The blast analysis of $16 \mathrm{~S}$ rRNA sequence of isolate BBK_9 strain reveals closer resemblance with the Burkholderia sp. A45 strain (Genebank accession number KF788025). The phylogenetic tree shows the evidence for identifying the isolate which is represented in Fig. 1. The phylogenetic tree of BBK_9 was constructed with those of the soil isolates, with 78-100\% homology to those of species that are known to be potent degraders of pesticides and heavy metals.

\section{Utilization of PCZ by Burkholderia sp. BBK_9 strain}

The bacterium Burkholderia sp. BBK_9 strain was tested for its PCZ degrading capability and the biodegradation was achieved up to $8.89 \mu \mathrm{g} \mathrm{ml}^{-1}(88.87 \%)$ after the incubation of 4 days. Bacterial growth and degradation was measured at 600 and $220 \mathrm{~nm}$, respectively. In the meantime, no abiotic loss was observed in the control flasks and its proof is given in the Fig. 2.

\section{Effect of temperature and $\mathrm{pH}$ on PCZ degradation}

It was evident that, the upper and lower temperatures are responsible to affect the degradation rate of PCZ. The maximum degradation was achieved at optimum condition $30{ }^{\circ} \mathrm{C}$ with degradation up to $89.31 \%$. However, the degradation rate was decreased up to $47.73 \%$ at $20{ }^{\circ} \mathrm{C}$ and $10.55 \%$ at $60{ }^{\circ} \mathrm{C}$ (Fig. 3a). Likewise, the degradation rate of PCZ also gets affected by higher and lower $\mathrm{pH}$ values, pH $7(90.31 \%)$ was found optimum condition and least degradation was obtained at $\mathrm{pH} 3(11.19 \%)$ and $\mathrm{pH} 11$ (13.94\%) (Fig. 3b).

\section{Biodegradation analysis}

The standard PCZ was eluted at the retention time $6.8 \mathrm{~min}$ (Fig. 4a) with single peak and also in D0 (before inoculation of bacterial suspension) and mass of PCZ was determined by the mass spectra at $m / z 342.22$. However, culture filtrate extracted on the first, second, third and fourth days showed the considerable decrease in the PCZ peak with the formation of other metabolite peaks, which confirms degradation of PCZ. It is necessary to consider that, the culture filtrates extracted in different days showed the two important stable metabolites (M1 and M2) having retention time of 0.9 and $1.3 \mathrm{~min}$, respectively, and also other metabolites were mineralized during entire degradation process. Further during fourth day at 4.3 min other compound (M3) was detected (Fig. 4b). Metabolites were extracted by preparative HPLC and identified by
Fig. 1 Phylogenetic tree analysis of PCZ degrading strain, constructed through neighbor-joining method with bootstrap values as percentage at the nodes

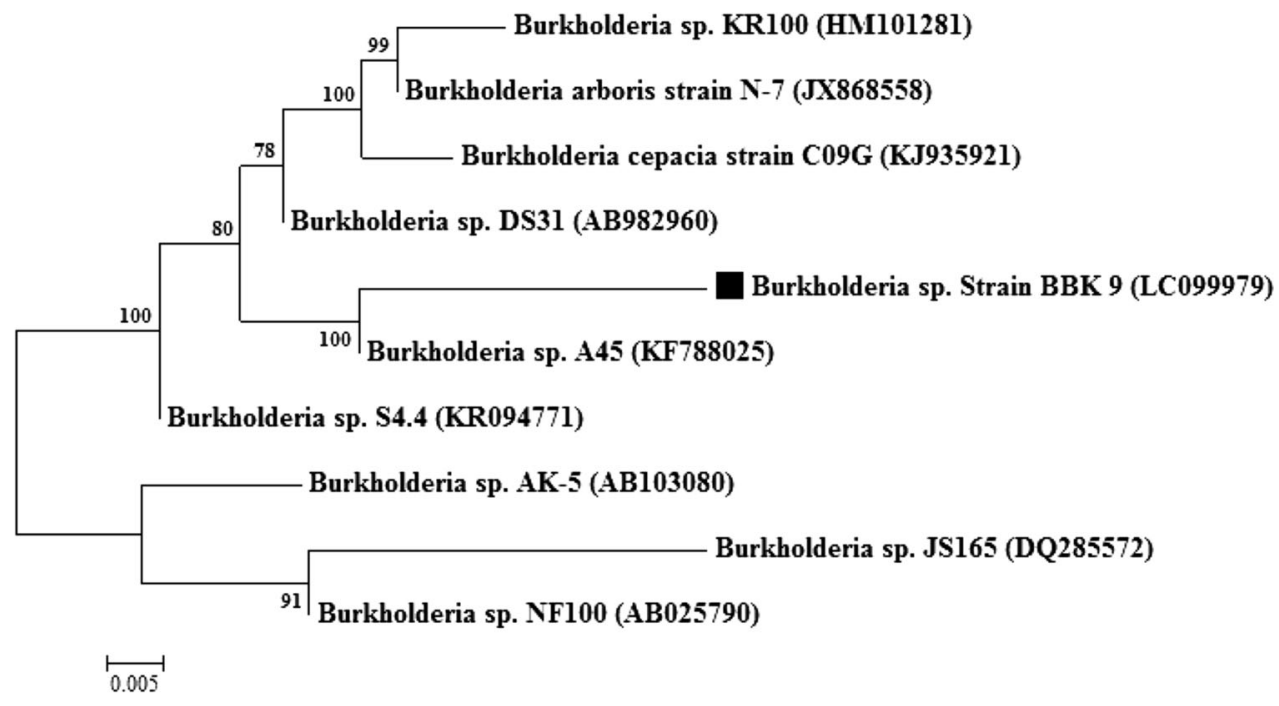


Fig. 2 Time course degradation of PCZ. Degradation rate (- - -) vs. bacterial cell growth of strain BBK_9 regarding to the alteration in turbidity $\left(-\mathbf{A}_{-}\right)$and uninoculated controls (--) in the mineral salt media. Error bars represents mean \pm standard error (SE) of three replicates

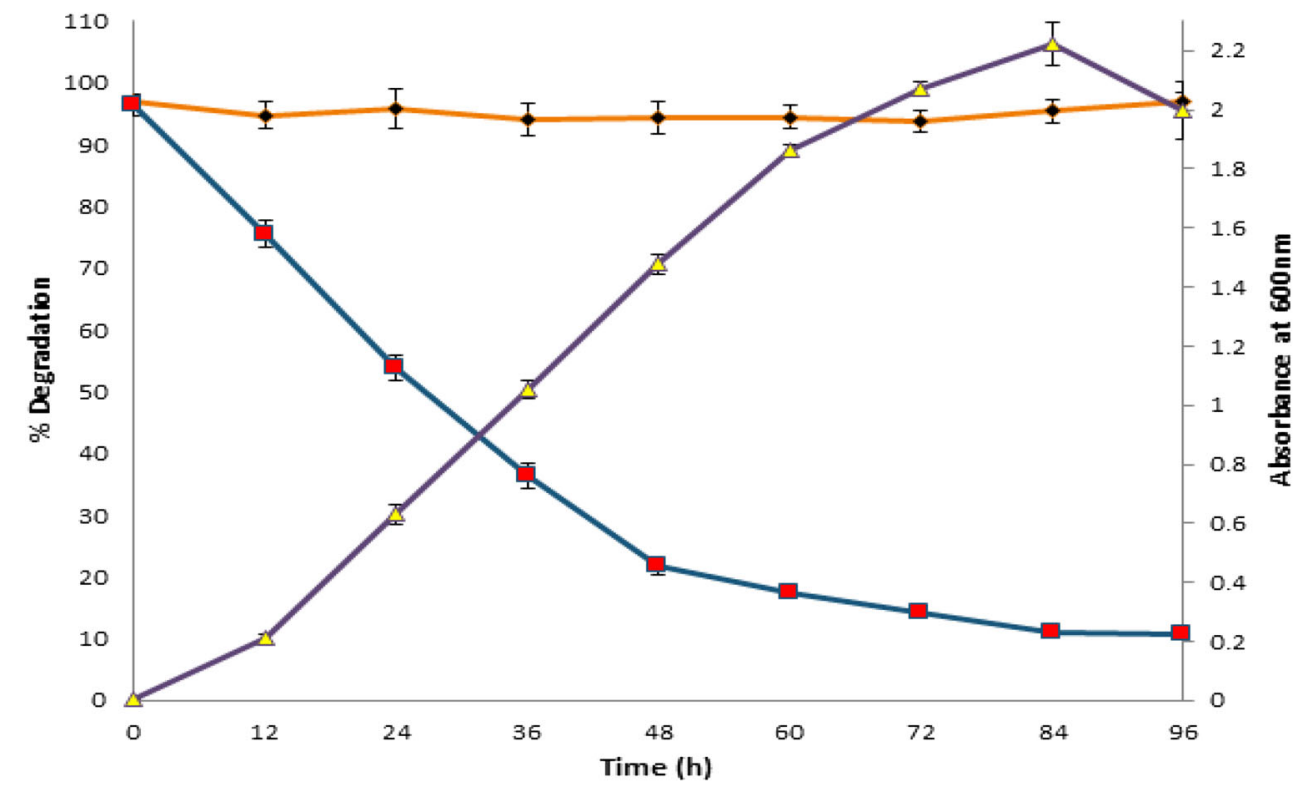

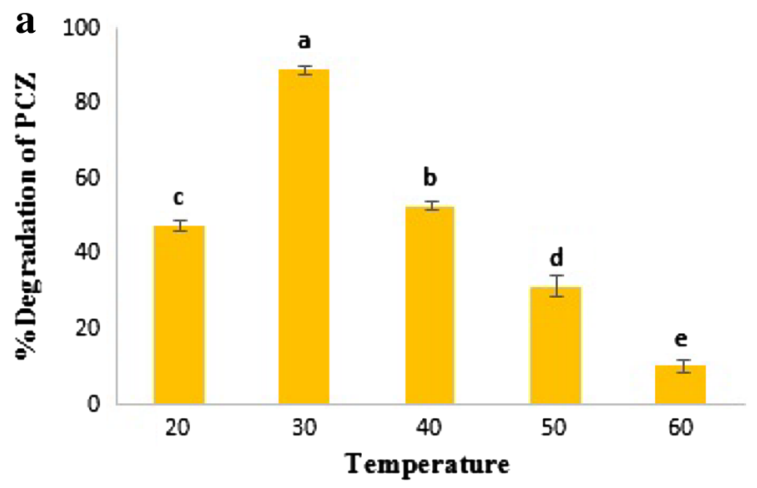

b

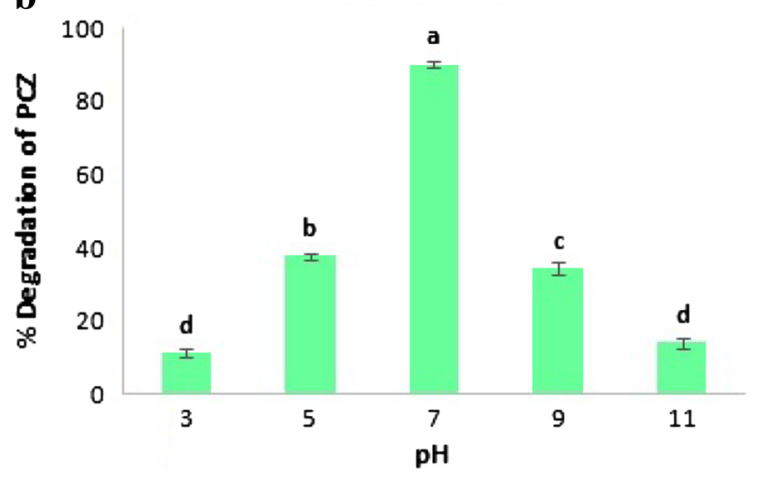

Fig. 3 a Effect of temperature on degradation rate of PCZ. b Impact of $\mathrm{pH}$ on degradation of $\mathrm{PCZ}$. All the values are mean $\pm \mathrm{SE}$ for each experiment are significantly different $(P \leq 0.05)$ from each other according to Duncan's test

fragmentation pattern and $m / z$ values such as 1-(2,4dichlorophenyl)-2-(1H-1,2,4-triazol-1-yl) ethanone $(\mathrm{m} / \mathrm{z}$ 256) (M1), 1-[2-(4-chlorophenyl) ethyl]-1H-1,2,4-triazole $(\mathrm{m} / \mathrm{z}$ 207) (M2) and 1-ethyl-1H-1,2,4-triazole $(\mathrm{m} / \mathrm{z}$ 98), respectively. The structural confirmations of all metabolite were assigned from the fragmentation and $\mathrm{m} / \mathrm{z}$ values procured. The proposed pathway for the PCZ degradation is showed in Fig. 5.

\section{LD50 value determination and plasmid curing of isolate BBK_9}

LD50 value was determined by amending the acridine orange in media inoculated with BBK_9 strain. LD50 value of BBK_9 strain was observed to be $40 \mu \mathrm{g} \mathrm{ml}^{-1}$ at cell density of 0.243 at $660 \mathrm{~nm}$, which is 0.443 half the density of the control. The plasmid curing of BBK_9 strain was performed by LD50 concentration up to sixth generation, the presence or absence of plasmid at every generation was analyzed by isolating it. It was found that, the three plasmids were present at approximately $23.13,9.14$ and $4.36 \mathrm{~kb}$, respectively, plasmids were hampered after the second generation. It indicates that, the curing process has taken place and the complete plasmid curing was observed at sixth generation (Fig. 6). Furthermore, plasmid cured strain was examined for its PCZ degradation capacity, which showed that, the substantial growth of plasmid cured organism in MSM was attained with degradation of PCZ up to $7.37 \mu \mathrm{g} \mathrm{ml}^{-1}$ at the initial concentration of $10 \mu \mathrm{g} \mathrm{ml}^{-1}$ (Fig. 7).

\section{Discussion}

In this study, we have isolated most impending candidate for degrading the PCZ from the fungicide contaminated paddy soil. It was evident that, the population of 
a

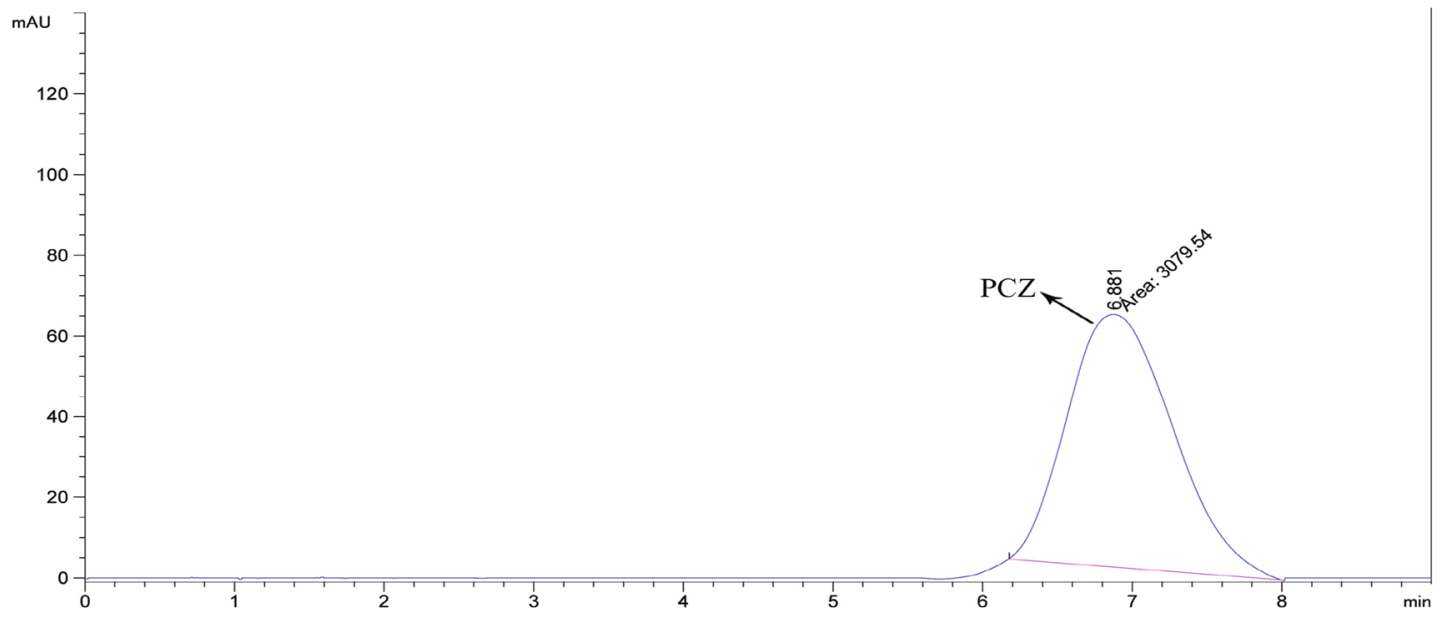

$\mathbf{b}$

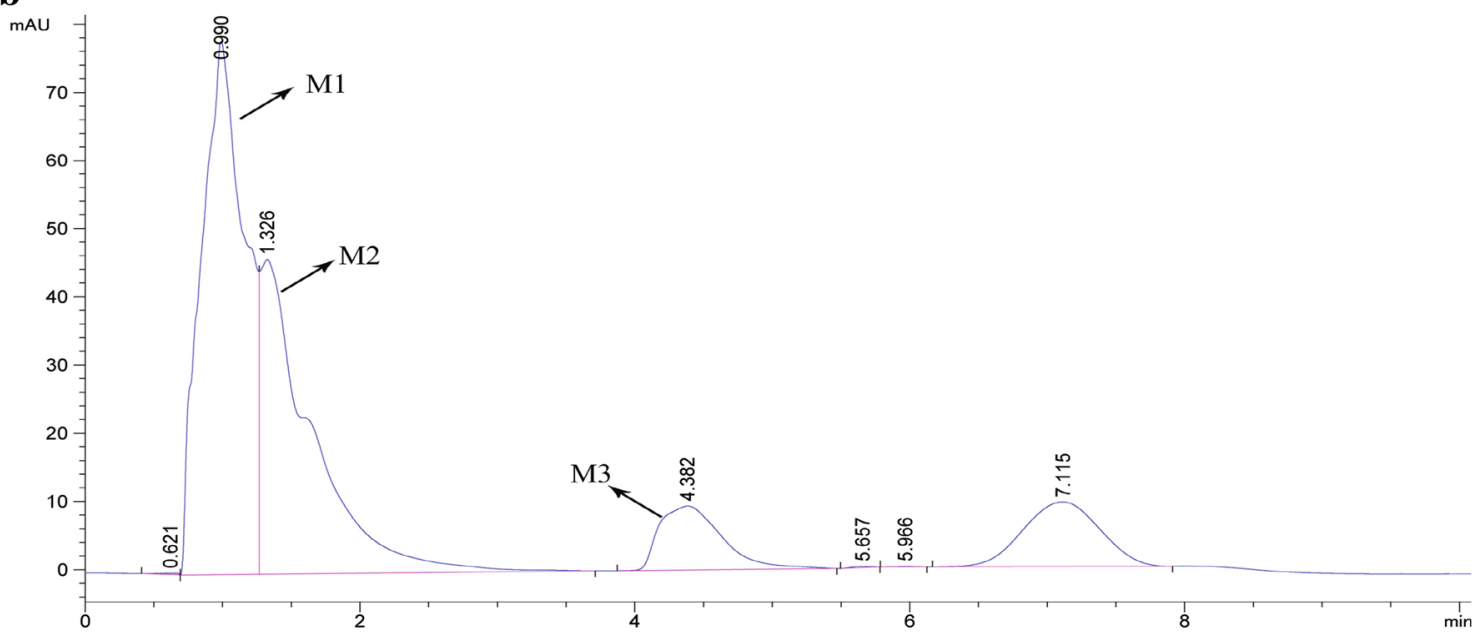

Fig. 4 a HPLC peak of standard propiconazole. b HPLC peak of 4 days incubated cell free culture filtrate showing presence of metabolites

Burkholderia sp. was observed to be predominant in the paddy soil and the bacterium Burkholderia sp. BBK_9 strain was evidenced for its ability to utilize PCZ as sole carbon and growth substrate in liquid medium resulting $8.89 \mu \mathrm{g} \mathrm{ml}^{-1}(88.87 \%)$ of degradation under the optimal conditions $\mathrm{pH} 7$ and $30{ }^{\circ} \mathrm{C}$. The preparative HPLC method came across as the most useful method for extracting and identifying the metabolites. Furthermore, culture filtrate yielded three precursors of PCZ degradation namely, 1-(2, 4-dichlorophenyl)-2-(1H-1, 2, 4-triazol-1-yl) ethanone (M1), 1-[2-(4-chlorophenyl) ethyl]-1H-1, 2, 4-triazole (M2) and 1-ethyl-1H-1,2,4-triazole (M3). Based on the fragmentation pattern M1 was identified with degradation of dioxolane ring from the PCZ representing the degradation product with molecular weight of 256. Simultaneously, M2 resulted from the loss of PCZ dioxolane ring and elimination one chlorine atom from the PCZ with molecular weight of 207. Metabolite M3 is identified by the loss of 1-chloro-4-methylbenzene with $\mathrm{m} / \mathrm{z}$ value of 98 . This experimental study would throw the light on plasmid role in the degradation. Moreover, plasmid cured strain was also an able contender in degrading the PCZ and it was clear that plasmid encoded genes does not play any role in the degradation process.

Isolation of pesticide resistance bacteria from the contaminated soil is the initial stage to understand the microbial population and to evaluate their tolerant capacity to the particular environment. Previously, Goda et al. (2010) isolated the five malathion degrading bacteria from Egyptian soil, among the all isolates Pseudomonas putida strains were chosen to conduct the degradation study due to their high efficacy and the important of this strain is revealed by repeated enrichment isolation method. The another research from united kingdom reveals the potential of isolation and screening of perithroid degrading bacteria which is isolated from the soil and in this study the potent bacterial strains were screened based on colony morphology which is having largest size (Grant et al. 2002). 
Fig. 5 Proposed degradation pathway of propiconazole by Burkholderia sp. BBK_9 strain

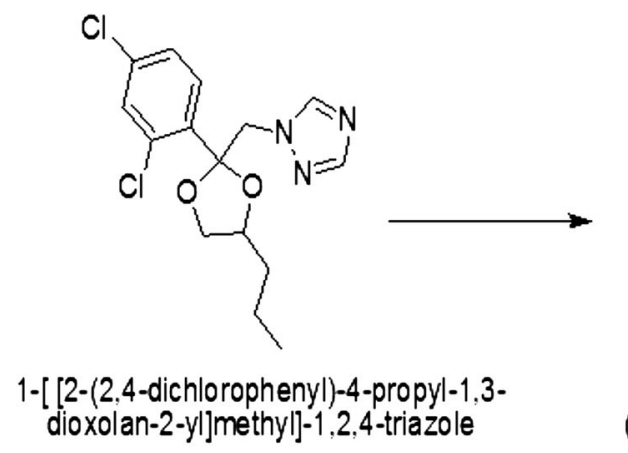

Mol. Wt.: 342.22

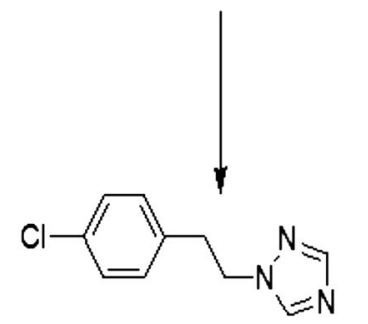

1-(4-chlorophenethyl)-1H-1,2,4-triazole

Mol. Wt.: 207.66

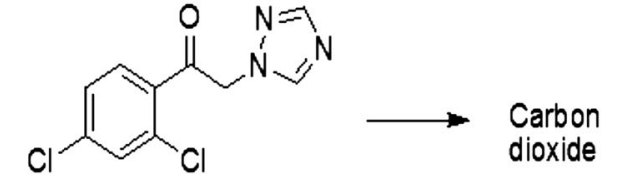

1-(2,4-dichlorophenyl)-2-

$(1 H-1,2,4-$ triazol-1-yl)ethanone

Mol. Wt: 256.09

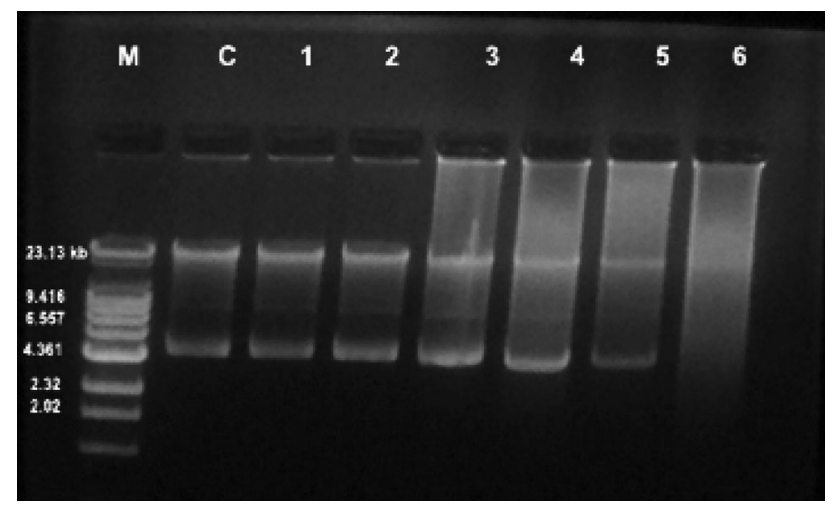

Fig. 6 The effect of curing agent acridine orange on BBK_9 strain; lane1 Marker, lane 2 control, lane 3 and 4 showing the presence of plasmids in the first and second generation, lane 5, 6 and 7 plasmid curing with hampered plasmid at the third, fourth and fifth generation, lane 8 complete curing of plasmid at sixth generation

Paracoccus sp. strain TRP was able degrader of chlorpyrifos (CP) and 3,5,6-trichloro-pyridinol (TCP) and it was the supreme candidate for the degradation of both the compounds in higher concentration than the other isolated strains and the screening of all strains were evaluated by CP and TCP utilizing capacity (Xu et al. 2008). This suggesting the screening for the potent strain in the biodegradation study is most important parameter.

In general, Burkholoderia is a genus of proteobacteria which is having impressive applications in the field of agricultural, as a potent agent in the process of biodegradation, biocontrol, and plant growth-promoting rhizobacteria (Estrada-de Los Santos et al. 2013) and also reported for its potentiality for degrading pesticides (Hong et al. 2007; Kim and Ahn 2008; Pimmata et al. 2013). Degradation of many pesticides by microorganisms under the in vitro conditions is mainly temperature and $\mathrm{pH}$ dependent. In support to this study, Kim et al. (2002) have given the evidence that temperature will be the major key to degradation of PCZ. Standardization of optimized parameters has significant influence over any biodegradation process and also reported that acidic and alkaline conditions were not suitable for degradation experiments due to their ability in limiting the growth of bacteria (Phugare et al. 2012). Recently, Talwar et al. (2014) has reported the studies on optimized conditions in degrading the quinalphos. Interestingly, PCZ degradation is assisted by $\mathrm{UV}$ in the presence of titanium dioxide $\left(\mathrm{TiO}_{2}\right)$ as a catalyst in aqueous solution under optimum conditions like $\mathrm{pH}(6.5)$, intensity of light $\left(30 \mathrm{Wm}^{-2}\right)$ and constant temperature $\left(25 \pm 1{ }^{\circ} \mathrm{C}\right)$ during the period of experiment (Kaur et al. 2015). The physical parameters (pH and temperature) will have greater influence on the degradation of PCZ.

A limited information is available for microbial degradation of PCZ, in support to our current study, Sarkar et al. (2009) suggesting, $P$. putida is the most effective candidate for the utilization of PCZ under the liquid medium and also carbon source like glucose will enhance the process of degradation. Although, none of the PCZ metabolites were 
Fig. 7 HPLC chromatogram of propiconazole extracted through culture filtrate of plasmid cured strain showing the degradation up to $7.37 \mu \mathrm{g} \mathrm{ml}^{-1}$

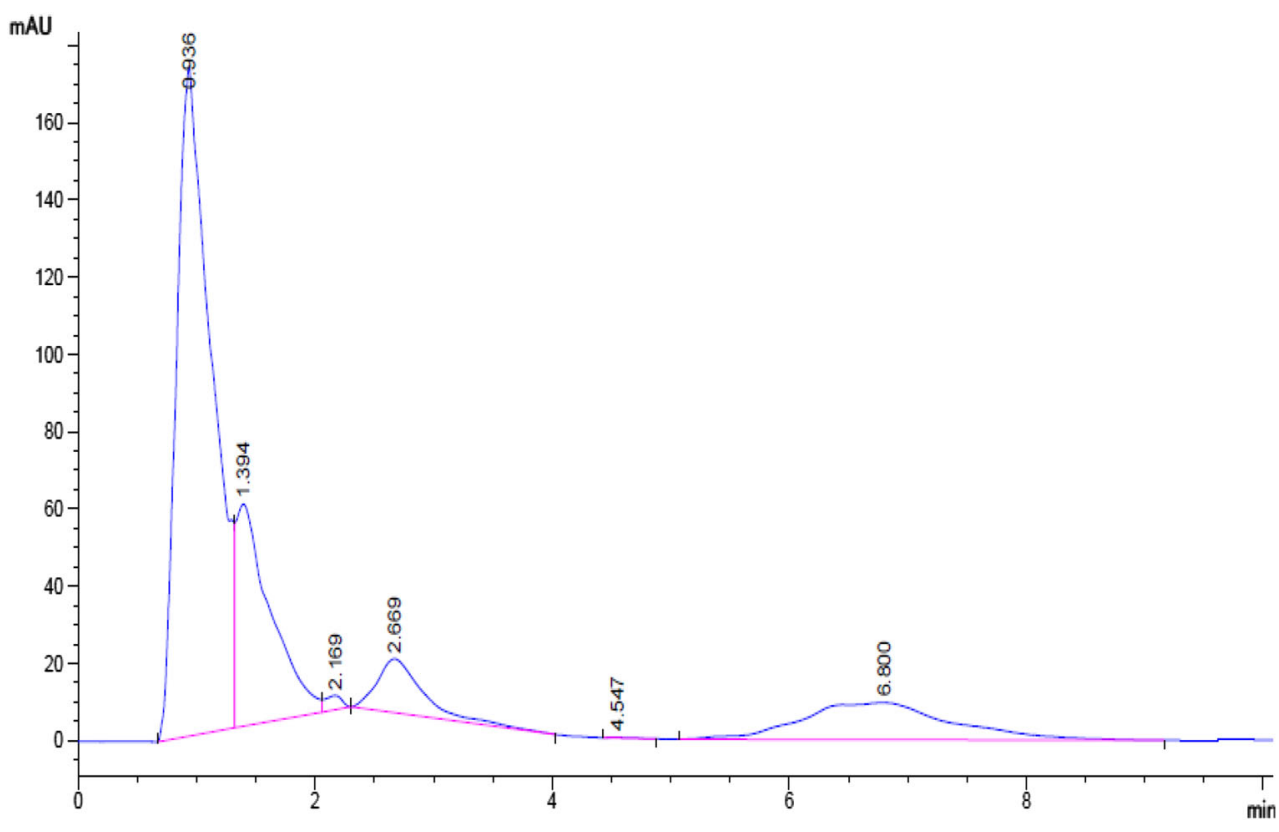

not reported. More importantly, metabolic pathway of PCZ by Burkholderia sp. BBK_9 is reported for the first of its kind. The white rots, brown rots and moulds were investigated by wood matrix method for their degradation capacity of carbon based preservatives, and it was achieved up to $75 \%$ of degradation applied at $1.39 \mathrm{~kg} \mathrm{~m}^{-3}$ (Woo et al. 2010). Above mentioned two literatures suggests that carbon sources will be the major key factor in degrading PCZ under different method of degradation process. It indicates that influence of energy source will have the impact on degradation mechanism.

Correspondingly, Kim et al. (2002) studied the fate of PCZ in paddy soil lysimeter and possible metabolites. Namely, 1-[[2(2,4-dichlorophenyl)-2-(1,2,4-triazole-1-yl) ketone (DP1), 1-(2,4-dichlorophenyl)-2-(1,2,4-triazole-1yl) ethanol (DP2) and 1[[2(2,4-dichlorophenyl)-4-hydroxypropyl-1,3-dioxolane-2-yl]methyl] $1 H$-1,2,4triazole. Further, carbon dioxide and bound residue were found to be metabolites of the PCZ. The metabolite DP2 was found similar in our investigation, this supports the present experimental results. Importantly, the dioxolane ring degradation from the PCZ is the initial step in degradation process. Vialaton et al. (2001) studied the photolysis of PCZ in pure water, in water containing humic substances and in natural water, it was revealed that PCZ was photo degraded and the dissolution of PCZ was found $25 \%$ faster in natural water then the pure water. Similarly, the fate of PCZ degradation in canal water was tested under the laboratory conditions; which showed the dissipation of PCZ up to $80 \%$ (Chauhan et al. 2008). Worryingly, the triazole fungicides are used more than the other group of fungicides but the studies regarding microbial degradation have been vastly under represented. Additionally, PCZ is major triazole agent, it is known to be highly persistent in soil and it will prevent the microorganisms from existing in the soil with long term effect (Yen et al. 2009). Importantly, the fungicides were never classified and characterized according to their mode of action, it indicates the problems for the assessing the non-target effect. Conversely, for the protection of biological functions and soil fertility, selection of fungicides is very important to prevent the nontarget effects (Yang et al. 2011).

Previously, five triazole fungicides were investigated for their degradation ability in peaches field by photo degradation method. Expect PCZ, residual levels of cyproconazole, penconazole, tebuconazole and hexaconazole were found higher the recommended limits at preharvest time. Further, it is also reported that PCZ is highly stable and it will decrease in concentration during the plant growth by diluting effect, it indicates that PCZ is the stable among the other triazoles (Angioni et al. 2003). Additionally, triazole fungicides are globally used for the commercial purpose and most of them are known to be persistent in soil for longer duration and the studies over field have suggests that traces of triazoles will have impact on the soil fertility along with crop yielding (Bromilow et al. 1999). Triazole fungicide often shares a same mode of actions ( $\mathrm{Li}$ et al. 2013; Satapute and Kaliwal 2015). Hence, Burkholderia sp. BBK_9 strain may also be useful in degrading the other triazole pesticides.

Plasmid cured strain was well distinguished for gaining of the resistance over PCZ in current study; it indicates that chromosomal genes are directly responsible for degrading the PCZ by BBK_9 strain. However, only few bacteria 
were isolated which carry an extra chromosomal DNA. The plasmid cured Pseudomonas aeruginosa MCMB-427 strain was found unable in degrading the dimethoate in liquid media. Suggesting, plasmid (designated as pDMD427) has direct involvement in the degradation (Deshpande et al. 2001). Interestingly, other plasmid cured Pseudomonas aeruginosa strain which is heavy metal resistant strain found potent candidate to utilize cadmium, chromium and lead indicating that it contains chromosomal genes in degradation mechanism (Raja and Selvam 2009). In case of degradation of fenitrothion, Burkholderia sp. strain NF100 is the supreme agent and it was investigated that degradation was encoded by the involvement of plasmids designated as pNF1 and pNF2 (Hayatsu et al. 2000). The slow rate of imidacloprid degradation was found by plasmid cured Brevundimonas sp. MJ15 strain. Interestingly, the degradation was archived up to $50 \%$ lesser than the uncured strain. Suggesting, both chromosomal and extra chromosomal genes may involve in degradation process of imidacloprid (Shetti and Kaliwal 2012). Whereas, plasmid of Pseudomonas aeruginosa contains the plasmid encoded genes which take part in the degradation mechanism of methomyl (Kulkarni and Kaliwal 2014). Thus, the use of Burkholderia sp. BBK_9 strain for biodegradation of hazardous chemicals to make toxic-free environment is possible.

\section{Conclusion}

In this experimental study, the isolation of a potent Burkholderia sp. strain BBK_9 was done from paddy soil and also its ability to utilize PCZ was assessed. The isolate was able to transform PCZ into three important metabolites. These experimental results suggested that isolate degraded PCZ up to $8.89 \mu \mathrm{g} \mathrm{ml}^{-1}$ (89\%). Along with that the strain preserved its ability to utilize $\mathrm{PCZ}$ at $30^{\circ} \mathrm{C}$ and $\mathrm{pH}$ 7. Plasmid cured cells were also a healthy competitor which can degrade the PCZ. Indicating additional studies to advance more widen view over PCZ degrading enzymes and gene from Burkholderia sp. BBK_9 strain. Thus, results of this study showed that the Burkholderia sp. strain BBK_9 can play a role as significant biological candidate for cleaning up of the contaminated pollutants.

\section{Compliance with ethical standards}

Conflict of interest The authors do not have any conflict of interest connected to the manuscript. Ethical approval this article does not contain any studies with human participants or animals performed by any of the authors.

Ethical approval This article does not contain any studies with human participants or animals performed by any of the authors.
Open Access This article is distributed under the terms of the Creative Commons Attribution 4.0 International License (http:// creativecommons.org/licenses/by/4.0/), which permits unrestricted use, distribution, and reproduction in any medium, provided you give appropriate credit to the original author(s) and the source, provide a link to the Creative Commons license, and indicate if changes were made.

\section{References}

Angioni A, Aguilera Del Real A, Russo M, Melis M, Cabitza F, Cabras P (2003) Triazole fungicide degradation in peaches in the field and in model systems. Food Addit Contam 20:368-374

Bromilow RH, Evans AA, Nicholls PH (1999) Factors affecting degradation rate of triazole fungicides in two soil types: II field studies. Pest Manag Sci 55:1135-1142

Chauhan R, Chopra I, Kumari B (2008) Degradation of propiconazole in canal water under laboratory conditions. Pestic Res 20:136-137

Cycon M, Wojcik M, Piotrowska-Seget Z(2011) Biodegradation kinetics of the benzimidazole fungicide thiophanate-methyl by bacteria isolated from loamy sand soil. Biodegradation 22:573-583

Deshpande NM, Dhakephalkar PK, Kanekar PP (2001) Plasmidmediated dimethoate degradation in Pseudomonas aeruginosa MCMB-427. Lett Appl Microbiol 33:275-279

Ekler Z (1988) Behaviour of thiophanate herbicides in soil: adsorption and volatilization. Pestic Sci 22:145-157

Estrada-de Los Santos P, Vinuesa P, Martínez-Aguilar L, Hirsch AM, Caballero-Mellado JS (2013) Phylogenetic analysis of Burkholderia species by multilocus sequence analysis. Curr Microbiol 67(1):51-60

Goda SK, Elsayed EE, Khodair TA, Walaa El-Sayed, Mohamed ME (2010) Screening for and isolation and identification of malathiondegrading bacteria: cloning and sequencing a gene that potentially encodes the malathion-degrading enzyme, carboxylestrase in soil bacteria. Biodegradation 21:903-913. doi:10.1007/s10532-010-9350-3

Grant RJ, Daniell TJ, Betts WB (2002) Isolation and identification of synthetic pyrethroid-degrading bacteria. J Appl Microbiol 92:534-540

Hayatsu M, Hirano M, Tokuda S (2000) Involvement of two plasmids in fenitrothion degradation by Burkholderia sp. strain NF100. Appl Environ Microbiol 66:1737-1740

Hong Q, Zhang Z, Hong Y, Li S (2007) A microcosum study on bioremediation of fenitrothion-contaminated soil using Burkholderia sp. FDS-1. Bioremed Biodegrad 59:55-61

Kaur T, Toor AP, Wanchoo RK (2015) UV-assisted degradation of propiconazole in a $\mathrm{TiO}_{2}$ aqueous suspension: identification of transformation products and the reaction pathway using GC/MS. Int J Environ Anal Chem 95:494-507

Kim JR, Ahn YJ (2008) Identification and characterization of chlorpyrifos-methyl and 3,5,6-trichloro-2-pyridinol degrading Burkholderia sp. strain KR100. Biodegradation 20(4):487-497

Kim IS, Beaudette LA, Shim JH, Trevors JT, Suh YT (2002) Environmental fate of the triazole fungicide propiconazole in a rice-paddy-soil lysimeter. Plant Soil 239:321-331

Kloskowski R, Fuhr F, Mittelstaedt W (1987) The uptake of nonextractable soil-bound pesticide residues by roots-standardized experiments with four pesticides. In: Greenhalgh R, Roberts TR (eds) Pesticide science and biotechnology. Blackwell Scientific, Oxford, pp 405-410

Kulkarni AG, Kaliwal BB (2014) Bioremediation of methomyl by soil isolate-Pseudomonas aeruginosa. J Environ Sci, Toxicol Food Technol 8(12):1-10 
Lee JB, Sohn HY, Shin KS, Kim JS, Jo MS, Jeon CP, Jang JO, Kim JE, Kwon GS (2008) Microbial biodegradation and toxicity of vinclozolin and its toxic metabolite 3,5-dichloroaniline. J Microbiol Biotechnol 18:343-349

Li Y, Dong F, Liu X, Xu J, Chen X, Han Y, Liang X, Zheng Y (2013) Studies of enantiomeric degradation of the triazole fungicide hexaconazole in tomato, cucumber, and field soil by chiral liquid chromatography-tandem mass spectrometry. Chirality 25:160-169

Megadi BV, Tallur NP, Mulla IS, Ninnekar HZ (2010) Bacterial degradation of fungicide captan. J Agric Food Chem 58:12863-12868

Nicole TS, Priscila SC, Maria DCR, Peralbaand Marco AZA (2009) Biodegradation of tebuconazole by bacteria isolated from contaminated soils. J. Environ Sci Health B Pestic Food Contam Agric Wastes 45:67-72

Phugare SS, Gaikwad YB, Jadhav JP (2012) Biodegradation of acephate using a developed bacterial consortium and toxicological analysis using earthworms (Lumbricus terrestris) as a model animal. Int Biodeterior Biodegrad 69:1-9

Pimmata P, Reungsang A, Plangklang P (2013) Comparative bioremediation of carbofuran contaminated soil by natural attenuation, bioaugmentation and biostimulation. Int Biodeterior Biodegrad 85:196-204

Raja CE, Selvam GS (2009) Plasmid profile and curing analysis of Pseudomonas aeruginosa as metal resistant. Int J Environ Sci Technol 6(2):259-266

Ramudu AC, Jaffer Mohiddin G, Srinivasulu M, Madakka M, Rangaswamy V (2011) Impact of fungicides chlorothalonil and propiconazole on microbial activities in groundnut (Arachishypogaea L.) soils. ISRN Microbiol, 2011:1-7

Rokade K, Mali G (2014) Biodegradation of benzyl benzoate by Pseudomonas desmolyticum NCIM 2112. World J microbial Biotechnol 30:827-833

Saitou N, Nei M (1987) The neighbor-joining method: a new method for reconstructing phylogenetic trees. Mol Biol Evol 4:406-425

Sarkar S, Seenivasan S, Premkumar R (2009) Biodegradation of propiconazole by Pseudomonas putida isolated from tea rhizosphere. Plant soil environ 55:196-201
Satapute PP, Kaliwal BB (2015) In vitro toxicityscreening of triazole fungicide propiconazole. Int J Recent Sci Res 6(9):6525-6528

Seubert W (1960) Degradation of isoprenoid compounds by microorganisms. I. Isolation and characterization of an isoprenoiddegrading bacterium, Pseudomonas citronellolis n. sp. J Bacteriol 79:426-434

Sherif AM, Elhussein AA, Osman AG (2011) Biodegradation of fungicide thiram (TMTD) in soil under laboratory conditions. Am J Biotechnol Mol Sci 1:57-68

Shetti AA, Kaliwal BB (2012) Biodegradation of imidacloprid by soil isolates Brevundimonas sp. MJ15. Int J Curr Res 4(10):100-106

Talwar MP, Mulla SI, Ninnekar HZ (2014) Biodegradation of organophosphate pesticide quinalphosby Ochrobactrum sp. strain HZM. J Appl Microbiol 117:1283-1292

Tamura K, Nei M (1993) Estimation of the number of nucleotide substitutions in the control region of mitochondrial DNA in humans and chimpanzees. Mol Biol Evol 10:512-526

Thorstensen CW, Lode O (2001) Laboratory degradation studies of bentazone, dichlorprop, MCPA, and propiconazole in Norwegian soils. J Environ Qual 30:947-953

Vialaton D, Pilichowski JF, Baglio D, Payaperez A, Larsen B, Richard C (2001) Phototransformation of propiconazole in aqueous media. J Agric Food Chem 49:5377-5382

Woo C, Daniels B, Stirling R, Morris P (2010) Tebuconazole and propiconazoletolerance and possible degradation by Basidiomycetes: a wood-based bioassay. Int Biodeterior Biodegradation 64:403-408

Xu G, Zhengc W, Li Y, Wangd S, Zhangc J, Yan Y (2008) Biodegradation of chlorpyrifos and 3,5,6-trichloro-2-pyridinol by a newly isolated Paracoccus sp. strain TRP. Int Biodeterior Biodegrad 62:51-56

Yang C, Hamel C, Vujanovic V, Gang Y (2011) Fungicide: modes of action and possible impact on nontarget microorganisms. ISRN Ecol 1(1):1-8

Yen JH, Chang JS, Huang PJ, Wang YS (2009) Effects of fungicides triadimefon and propiconazole on soil bacterial communities. J Environ Sci Health B 44:681-689 